\title{
Evaluation and Management of Severe Childhood Anemia: A Single Center Experience
}

\author{
Derin Çocukluk Çağı Anemisinin Değerlendirilmesi ve Yönetimi: Tek Merkez Deneyimi
}

\author{
Hatice Mine ÇAKMAK ${ }^{1}$ \\ (D) 0000-0003-3730-0982 \\ Mehmet Ali SUNGUR ${ }^{2}$ \\ (D) 0000-0001-5380-0819 \\ Kenan KOCABAY 3 \\ (D) 0000-0002-4030-1145
}

\begin{abstract}
Aim: The aim of this study was to determine the frequency of iron deficiency anemia in patients with severe anemia, and to investigate and compare the difference in the hematological parameters between patients with and without iron deficiency anemia.

Material and Methods: A total of 119 patients diagnosed with severe anemia between January 2012 and July 2014 were retrospectively analyzed in this study. Demographic and clinical characteristics of severe anemia patients were evaluated. Patients were evaluated in terms of iron deficiency anemia, and clinical characteristic and laboratory findings of the patients with and without iron deficiency anemia were compared.

Results: Of the 119 cases $49(41.2 \%)$ were male and $70(58.8 \%)$ were female, mean age was $6.7 \pm 6.2$ years. Various comorbidities were present in the patients. In all patients, the group with a hemoglobin value below $6 \mathrm{~g} / \mathrm{dL}$ had a significantly lower platelet count than those equal to or above $6 \mathrm{~g} / \mathrm{dL}(\mathrm{p}=0.037)$. It was found that $52(43.7 \%)$ of all cases had iron deficiency anemia and $27(51.9 \%)$ of them were aged 5 to 18 years. Patients with iron deficiency anemia had lower ferritin level $(\mathrm{p}<0.001)$ than patients without iron deficiency anemia, while platelet count was higher in patients with iron deficiency anemia $(\mathrm{p}=0.001)$.

Conclusion: In patients with severe anemia, a significant decrease in platelet count was found with hemoglobin value below $6 \mathrm{~g} / \mathrm{dL}$. In order to reduce the need for red blood cells transfusion, early diagnosis of iron deficiency anemia is important and iron supplementation should be given earlier.
\end{abstract}

${ }^{1}$ Eskişehir City Hospital Department of Pediatric Hematology and Oncology, Eskişehir, Turkey

${ }^{2}$ Düzce University Faculty of Medicine Department of Biostatistics and Medical Informatics, Düzce, Turkey

${ }^{3}$ Düzce University Faculty of Medicine Department of Pediatrics, Düzce, Turkey

\section{Corresponding Author Sorumlu Yazar \\ Hatice Mine ÇAKMAK}

h.m.tokuc@hotmail.com

Received / Geliş Tarihi : 18.12 .2019 Accepted / Kabul Tarihi : 07.04.2020 Available Online /

Çevrimiçi Yayın Tarihi : 25.04.2020
Keywords: Severe anemia; childhood; iron deficiency anemia; blood transfusion.

ÖZ

Amaç: Bu çalışmanın amacı derin anemisi olan hastalarda demir eksikliği anemisi sıklığını belirlemek ve demir eksikliği anemisi olan ve olmayan hastalar arasında hematolojik parametrelerdeki farklılığı incelemek ve karşılaştırmaktır.

Gereç ve Yöntemler: Bu çalışmada Ocak 2012 ve Temmuz 2014 tarihleri arasında derin anemi tanısı almış olan toplam 119 hasta geriye dönük olarak incelendi. Derin anemi hastalarının demografik ve klinik özellikleri değerlendirildi. Hastalar demir eksikliği anemisi açısından değerlendirildi ve demir eksikliği anemisi olan ve olmayan hastaların klinik özellikleri ve laboratuvar bulguları karşılaştırıldı.

Bulgular: Yüz on dokuz olgunun $49(\% 41,2)$ 'u erkek, $70(\% 58,8)$ 'i kız olup ortalama yaş $6,7 \pm 6,2$ yıl idi. Hastalarda çeşitli eş zamanlı hastalıklar vardı. Tüm hastalarda, hemoglobin değeri $6 \mathrm{gr} / \mathrm{dL}$ 'nin altında olan grup, $6 \mathrm{gr} / \mathrm{dL}$ 'ye eşit ve üstünde olanlara göre anlamlı şekilde daha düşük trombosit sayısına sahipti $(\mathrm{p}=0,037)$. Tüm vakaların $52(\% 43,7)$ 'sinde demir eksikliği anemisi olduğu bulundu ve bunların $27(\% 51,9)$ 'si 5 ile 18 yaş arasında idi. Demir eksikliği anemisi olan hastaların ferritin düzeyi demir eksikliği anemisi olmayan hastalara göre daha düşük $(\mathrm{p}<0,001)$ iken, trombosit sayısı ise demir eksikliği anemisi olan hastalarda daha yüksekti $(\mathrm{p}=0,001)$.

Sonuç: Derin anemili hastalarda, hemoglobin değerinin $6 \mathrm{~g} / \mathrm{dL}$ 'nin altında olması durumunda trombosit sayısında anlamlı düşüş saptanmıştır. Eritrosit transfüzyonu ihtiyacını azaltmak için, demir eksikliği anemisinin erken teşhisi önemlidir ve demir takviyesi daha erken yapılmalıdır.

Anahtar kelimeler: Derin anemi; çocukluk çağı; demir eksikliği anemisi; kan transfüzyonu. 


\section{INTRODUCTION}

Anemia is defined as a hemoglobin and hematocrit value with two standard deviations below the mean for a certain age, with a confidence limit of $95 \%$ (1). In 2011, the World Health Organization (WHO) has reported cut-off points to classify anemia as mild, moderate, and severe (2). Severe anemia is defined as a hemoglobin level below $7 \mathrm{~g} / \mathrm{dL}$ in children aged 6 to 59 months, and below $8 \mathrm{~g} / \mathrm{dL}$ in other age groups. According to data from the WHO, half of the children diagnosed with anemia in developing countries have iron deficiency anemia while severe anemia is uncommon (3). However, the mortality of severe anemia can be increased by infections, malnutrition, poverty, and low availability of health care. It is very important to diagnose the cause of the anemia before any blood transfusions so that the appropriate treatment strategy can be determined (4). The aim of this study was to determine the frequency of iron deficiency anemia in patients hospitalized for severe anemia, to evaluate characteristics of the patients with iron deficiency anemia, and to investigate and compare the hematological parameters between the patients with and without iron deficiency anemia.

\section{MATERIAL AND METHODS}

A total of 119 patients hospitalized for severe anemia between January 2012 and July 2014 at Düzce University Medical Faculty, Departments of Pediatrics were retrospectively evaluated. Information was obtained retrospectively from the patient charts and by contacting the families by phone. All patients had severe anemia according to their age group reference value at the time of first admission. The age range was 2.5 months to 17.5 years, and divided into three groups as $<6$ months, 6 months to 5 years and 5 to 18 years. The lower limit of hemoglobin for severe anemia was accepted as $7 \mathrm{~g} / \mathrm{dL}$ in children under 6 months of age, $7 \mathrm{~g} / \mathrm{dL}$ in children aged 6 months to 5 years, and $8 \mathrm{~g} / \mathrm{dL}$ in those older than 5 years (2).

Demographic and clinical characteristics of patients with severe anemia were evaluated. Severe anemia patients were divided into two groups according to hemoglobin values as the patients with a hemoglobin value above or below $6 \mathrm{~g} / \mathrm{dL}$, and these groups were compared in terms of laboratory values.

All the patients were evaluated in terms of iron deficiency anemia, demographic and clinical characteristics of the patients detected with iron deficiency anemia were also evaluated. Severe anemia patients were divided again into two groups as the patients with and without iron deficiency anemia. Two groups with and without iron deficiency anemia were compared in terms of their complaints, laboratory values and other clinical characteristics.

Blood indices contained hemoglobin, mean cell volume (MCV), mean cell hemoglobin $(\mathrm{MCH})$, mean cell hemoglobin concentration (MCHC), red blood cell distribution width (RDW), white blood cell (WBC) and platelet count were evaluated.

This study was approved by the Clinical Research Ethics Committee of Düzce University Medical Faculty on 25.04.2013 with decision number 2013/401 and was conducted according to the Helsinki Declaration principles. Statistical Analysis

The normality assumption for continuous variables was examined using Kolmogorov-Smirnov and Shapiro-Wilk tests. Continuous data were summarized with mean and standard deviation or median and interquartile range, as appropriate, according to normality assumption. Categorical variables were summarized as frequency and percentage. Independent Samples t test or Mann-Whitney $\mathrm{U}$ test was used to compare two groups in terms of continuous variables depending on whether the normality assumption was provided. Pearson chi-square or Fisher's exact tests were used to evaluate the relationships between categorical variables. A receiver operating characteristic (ROC) curve analysis was used to determine the diagnostic predictive ability and cut-off values of the continuous variables. Statistical analyzes were performed with the SPSS v.22 statistical package and a p value equal to or less than 0.05 was considered as statistical significance level.

\section{RESULTS}

Characteristics of Children with Severe Anemia

One hundred nineteen children aged between 0.25 and 17.5 with a mean of $6.7 \pm 6.2$ years had a hemogram value that was consistent with severe anemia. There were 49 (41.2\%) male and $70(58.8 \%)$ female patients. The patients were divided into three age groups as below 6 months, 6 months to 5 years and 5 to 18 years containing 5 (4.2\%), 61 (51.3\%) and $53(44.5 \%)$ patients, respectively. The complaints of children with severe anemia were loss of appetite in 81 $(68.1 \%)$, rapid fatigue in $76(63.9 \%)$, weight loss in 46 $(38.7 \%)$, pica in $9(7.6 \%)$, and parasites in $2(1.7 \%)$.

The severe anemia in study group was due to various disorders. Of the three most common causes, iron deficiency anemia was present in 52 patients $(43.7 \%)$, chronic disease anemia in 29 patients (24.4\%), and bleeding in 21 patients $(17.6 \%)$. Microangiopathic hemolytic anemia was detected in $5(4.2 \%)$, leukemia in 2 $(1.7 \%)$, hereditary spherocytosis in $4(3.4 \%)$, thalassemia major in $1(0.8 \%)$, sideroblastic anemia in $1(0.8 \%)$, and megaloblastic anemia in $1(0.8 \%)$, as the other less common causes (Table 1). There were $2(1.7 \%)$ patients diagnosed with transient erythroblastopenia of childhood. In addition to the main diagnoses evaluated above, 14 $(11.8 \%)$ patients had iron deficiency anemia or iron deficiency, 8 (6.7\%) patients had vitamin B12 deficiency, and $1(0.8 \%)$ patient had folate deficiency.

Table 1. Differential diagnosis of severe anemia patients

\begin{tabular}{lc}
\hline Etiology of Anemia & $\mathbf{n}(\boldsymbol{\%})$ \\
\hline Iron deficiency anemia & $52(43.7)$ \\
Chronic disease anemia & $29(24.4)$ \\
Bleeding & $21(17.6)$ \\
Hemolytic anemia & $5(4.2)$ \\
Hereditary spherocytosis & $4(3.4)$ \\
Leukemia & $2(1.7)$ \\
Childhood transient erythroblastopenia & $2(1.7)$ \\
Thalassemia major & $1(0.8)$ \\
Megaloblastic anemia & $1(0.8)$ \\
Chemotherapy & $1(0.8)$ \\
Sideroblastic anemia & $1(0.8)$ \\
\hline
\end{tabular}


Laboratory Parameters of Children with Severe Anemia Of the 119 patients $32(26.9 \%)$ had a hemoglobin value below $6 \mathrm{~g} / \mathrm{dL}$. The platelet counts were statistically significantly higher in patients with a hemoglobin value equal to or above $6 \mathrm{~g} / \mathrm{dL}$ compared to below $6 \mathrm{~g} / \mathrm{dL}$ $(\mathrm{p}=0.037)$. There was no statistically significant difference in terms of blood indices except platelet counts between two groups (Table 2).

Characteristics of Children with Severe Iron Deficiency Anemia

A total of $52(43.7 \%)$ cases with iron deficiency anemia were detected. Monthly income was 1500 Turkish liras (TL) or less in $40(76.9 \%)$ of these cases. This information was obtained by contacting the families by phone.

Fecal occult blood test results were present for 27 (51.9\%) patients with iron deficiency anemia. The fecal occult blood test was positive in $4(7.7 \%)$ cases. The tissue transglutaminase $\operatorname{IgA}$ assay was found to be elevated in $1(1.9 \%)$ patient (who also had celiac disease). The mean hemoglobin level was $10.5 \pm 1.9 \mathrm{~g} / \mathrm{dL}$ at the 10 -month follow-up. None of the severe iron deficiency anemia patients died.

Vitamin B12 deficiency was found in $5(9.6 \%)$ severe iron deficiency patients while folate deficiency was present in $1(1.9 \%)$ patient. Among the iron deficiency anemia patients, 14 (26.9\%) had inadequate intake, $10(19.2 \%)$ had abnormal uterine bleeding, and 13 (25.0\%) had bleeding. Two patients $(3.8 \%)$ had von Willebrand's disease, $3(5.8 \%)$ had menorrhagia, and $1(1.9 \%)$ had bleeding from esophageal varices.

Organomegaly or pathological lymphadenomegaly was not found in any patient with severe iron deficiency. Systemic diseases were detected in $23(44.2 \%)$ iron deficiency anemia patients and included pulmonary diseases (bronchiolitis, pneumonia, tuberculosis) in 7 (13.5\%) cases, neurological diseases (migraine, epilepsy, hydrocephalus, meningitis, cerebral palsy, mental retardation) in $6(11.5 \%)$ cases, renal diseases (renal cyst, pelviectasis) in $5(9.6 \%)$ cases, congenital heart disorders (atrial septal defect, etc.) in $2(3.8 \%)$ cases, gastrointestinal bleeding in $2(3.8 \%)$ cases, and celiac disease in $1(1.9 \%)$ case. Oral iron was administered to all of the cases in the iron deficiency group.

Comparison of Severe Anemia Patients with and without Iron Deficiency Anemia

There was anorexia in $33(63.5 \%)$ of the patients with iron deficiency and in $48(71.6 \%)$ of the patients without iron deficiency anemia $(\mathrm{p}=0.342)$. Quick fatigue was present in $30(57.7 \%)$ of the patients with iron deficiency and 46 $(68.7 \%)$ of the patients without iron deficiency anemia $(p=0.217)$. There was weight loss in $17(32.7 \%)$ of the patients with iron deficiency anemia and 29 (43.3\%) of the patients in the group without iron deficiency $(\mathrm{p}=0.239)$. A history of a parasitic infection was present in $2(3.8 \%)$ subjects in the iron deficiency anemia group but none of the patients without iron deficiency anemia. A history of pica was statistically significantly more common in patients with iron deficiency anemia $(\mathrm{p}=0.041)$, there were $7(13.5 \%)$ patients in the group with iron deficiency anemia and $2(3.0 \%)$ patients in the group without iron deficiency anemia.

Evaluation of the blood indices of the iron deficiency anemia patients revealed a mean hemoglobin value of
$6.7 \pm 0.9 \mathrm{~g} / \mathrm{dL}$ and a median leukocyte count of $7.3 \times 10^{3} / \mathrm{mm}^{3}$. Mean hemoglobin value was $6.4 \pm 1.3 \mathrm{~g} / \mathrm{dL}$ and median leukocyte count was $7.8 \times 10^{3} / \mathrm{mm}^{3}$ in patients without iron deficiency anemia, and there was no significant difference between groups in terms both of these parameters ( $p=0.113$ and $p=0.314$, respectively). The median platelet count was $360 \times 10^{3} / \mathrm{mm}^{3}$ in patients with iron deficiency anemia and it was significantly higher than patients without iron deficiency anemia $\left(232 \times 10^{3} / \mathrm{mm}^{3}, \mathrm{p}=0.001\right)$. There was a significant difference between two groups in terms ferritin $(\mathrm{p}<0.001)$. The median ferritin level was 10 $\mathrm{ng} / \mathrm{mL}$ in patients with iron deficiency anemia and 170 $\mathrm{g} / \mathrm{dL}$ in patients without iron deficiency anemia. The mean $\mathrm{MCH}$ value was $17.3 \pm 3.5 \mathrm{pg}$ and the mean $\mathrm{MCHC}$ value $28.8 \pm 1.9 \%$ in patients with iron deficiency anemia, while these parameters were $26.4 \pm 5.9 \mathrm{pg}$ and $31.9 \pm 4.2 \%$ in patients without iron deficiency anemia, respectively. Both the $\mathrm{MCH}$ and $\mathrm{MCHC}$ values were significantly lower in patients with iron deficiency anemia (both $\mathrm{p}$ values were $<0.001$ ). In patients with iron deficiency anemia, MCV values with a mean of $58.9 \pm 7.8 \mathrm{fL}$ was detected as significantly lower compared to the patients without iron deficiency anemia $(81.1 \pm 14.4 \mathrm{fL}, \mathrm{p}<0.001)$. The mean RDW value were $19.9 \pm 3.9 \%$ in patients with iron deficiency anemia and $16.9 \pm 6.5 \%$ in patients without iron deficiency anemia; and RDW value was higher in patients with iron deficiency $(\mathrm{p}=0.004$, Table 3$)$.

Table 2. Comparison of the hematology values of patients with a hemoglobin value below and above $6 \mathrm{~g} / \mathrm{dL}$

\begin{tabular}{lccc}
\hline & $\begin{array}{c}<\mathbf{6} \mathbf{g} / \mathbf{d L} \\
(\mathbf{n = 3 2})\end{array}$ & $\begin{array}{c}\mathbf{\geq 6} \mathbf{~ g / d L} \\
(\mathbf{n = 8 7})\end{array}$ & $\mathbf{p}$ \\
\hline MCV (fL) & $72.7 \pm 15.5$ & $70.9 \pm 16.3$ & 0.586 \\
MCH (pg) & $21.9 \pm 7.7$ & $22.6 \pm 6.4$ & 0.656 \\
MCHC (gr/dL) & $29.6 \pm 5.4$ & $30.8 \pm 2.8$ & 0.263 \\
RDW & $18.9 \pm 5.9$ & $17.9 \pm 5.6$ & 0.416 \\
WBC (x10 $/ \mathbf{L})$ & $7.5(4.6-11.5)$ & $7.7(5.8-12)$ & 0.519 \\
Platelet $\left(\mathbf{x 1 0} / \mathbf{m m}^{3}\right)$ & $198(82-382)$ & $303(185-430)$ & $\mathbf{0 . 0 3 7}$ \\
Ferritin $(\mathbf{n g} / \mathbf{m L})$ & $15(7-157)$ & $40(10-276)$ & 0.286 \\
\hline
\end{tabular}

MCV: Mean Cell Volume, MCH: Mean Cell Hemoglobin, MCHC: Mean Cell Hemoglobin Concentration, RDW: Red Blood Cell Distribution Width, WBC: White Blood Cell

Table 3. Comparison of the patients with and without iron deficiency anemia

\begin{tabular}{lccc}
\hline & $\begin{array}{c}\text { IDA } \\
(\mathbf{n = 5 2})\end{array}$ & $\begin{array}{c}\text { Non-IDA } \\
(\mathbf{n = 6 7})\end{array}$ & $\mathbf{p}$ \\
\hline Hemoglobin (g/dL) & $6.7 \pm 0.9$ & $6.4 \pm 1.3$ & 0.113 \\
MCV (fL) & $58.9 \pm 7.8$ & $81.1 \pm 14.4$ & $<\mathbf{0 . 0 0 1}$ \\
MCH (pg) & $17.3 \pm 3.5$ & $26.4 \pm 5.9$ & $<\mathbf{0 . 0 0 1}$ \\
MCHC (gr/dL) & $28.8 \pm 1.9$ & $31.9 \pm 4.2$ & $<\mathbf{0 . 0 0 1}$ \\
RDW & $19.9 \pm 3.9$ & $16.9 \pm 6.5$ & $\mathbf{0 . 0 0 4}$ \\
WBC (x10 $/ \mathbf{L})$ & $7.3(5.5-9.9)$ & $7.8(5.2-13.3)$ & 0.314 \\
Platelet $\left(\mathbf{x 1 0} / \mathbf{m m}^{\mathbf{3}}\right)$ & $360(234-492)$ & $232(114-356)$ & $\mathbf{0 . 0 0 1}$ \\
Ferritin $\left(\mathbf{n g} / \mathbf{m L}^{2}\right.$ & $10(3-21)$ & $170(37-464)$ & $<\mathbf{0 . 0 0 1}$
\end{tabular}

IDA: Iron Deficiency Anemia, MCV: Mean Cell Volume, MCH: Mean Cell Hemoglobin, MCHC: Mean Cell Hemoglobin Concentration, RDW: Red Blood Cell Distribution Width, WBC: White Blood Cell 
The cut-off value for the diagnosis of severe iron deficiency anemia was calculated as $\leq 66.5$ for $\mathrm{MCV}$ (AUC $=0.913,95 \% \mathrm{CI}=0.858-0.969, \mathrm{p}<0.001$ ) and $\geq 17.9$ for RDW (AUC=0.787, 95\% $\mathrm{CI}=0.704-0.870$, $\mathrm{p}<0.001$ ). Sensitivity and specificity values were $71.2 \%$ and $74.6 \%$ for RDW, while these values were $92.4 \%$ and $86.6 \%$ for $\mathrm{MCV}$, respectively (Figure 1).

\section{Transfusion in Severe Anemia}

One hundred nine $(91.6 \%)$ patients in total and $42(80.8 \%)$ patients in iron deficiency group required packed red blood cell transfusions because of co-morbid cardiorespiratory distress. Additionally, in the group of severe iron deficiency anemia $7(13.3 \%)$ patients had worsening respiratory distress because of previous pulmonary disease.

\section{DISCUSSION}

Severe anemia is an important global health problem and is most frequent in developing countries (4). Severe anemia prevalence is below $2.5 \%$ worldwide, except in African countries (5). We used the most recent criteria for anemia as published by the WHO in 2011 for the cut-off values. Iron deficiency is the most common cause of anemia in children with a prevalence in the general population exceeding $50 \%$ in countries with low socioeconomic status $(6,7)$. In our current study, iron deficiency anemia $(43.7 \%)$
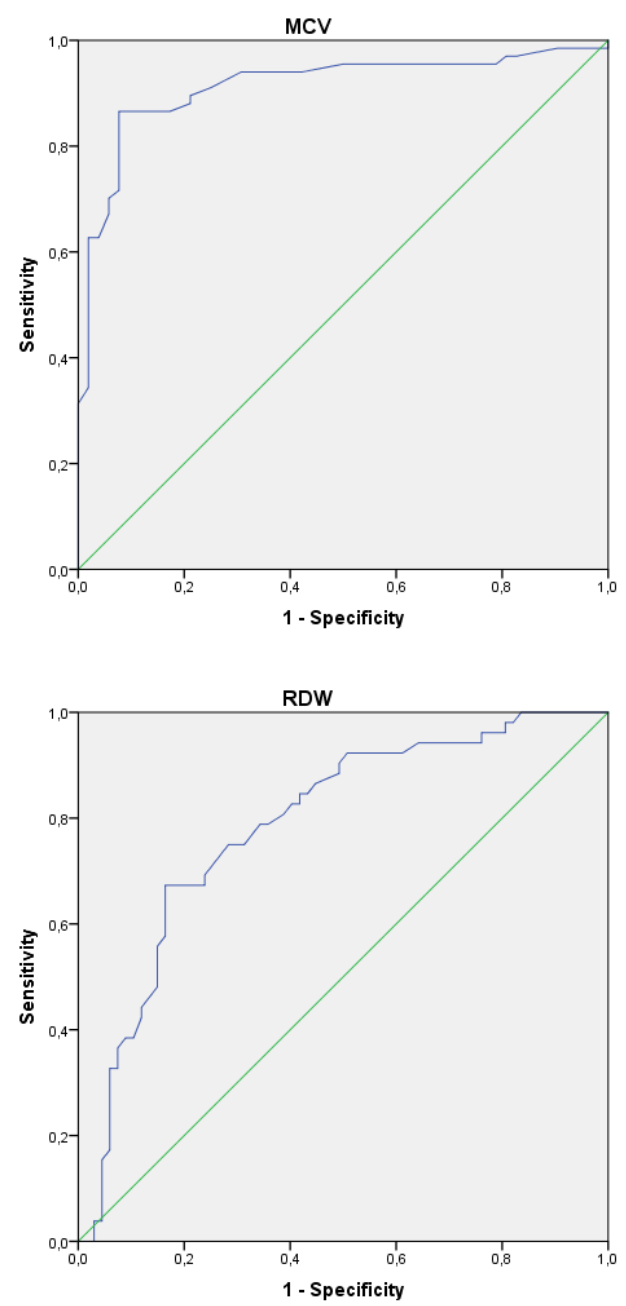

Figure 1. ROC (Receiver Operating Characteristics) curves for MCV (Mean Cell Volume) and RDW (Red Blood Cell Distribution Width) was the leading cause similarly. A study conducted in 1994 on severe anemia in childhood reported that $36.2 \%$ of the cases were diagnosed with iron deficiency anemia, $29.7 \%$ with malignancies and $12.3 \%$ with hemolytic anemia. The most common cause of severe anemia was reported as iron deficiency, followed by chronic disease and hemorrhage. And this study reported a higher rate of severe anemia in the group aged between 0-2 years (9). However, in our current study, the anemia rate was higher in children aged 6 months to 5 years compared to the other age groups studied. In another study conducted in $2005,44.5 \%$ of the patients with severe anemia aged 6 months to 6 years were diagnosed with iron deficiency anemia and $31 \%$ with anemia due to inflammation. This study also concluded that low socioeconomic level played a role in iron deficiency and severe anemia (10). We found that the family's monthly income was below $1500 \mathrm{TL}$ in most of the patients with iron deficiency anemia, as in this report. A study conducted in 2014 evaluated 28 hospitalized patients with severe anemia (hemoglobin $<7 \mathrm{~g} / \mathrm{dL}$ ) and iron deficiency anemia. The age range was 4 to 18 years and $42.8 \%$ of the adolescents were admitted with bleeding. Severe anemia due to iron deficiency was seen especially in the adolescent group, with less than half associated with bleeding, while the red meat consumption history suggested nutritional deficiency in all patients (11). The age groups were similar to our study but bleeding was not prominent in the etiology of our severe iron deficiency anemia patients. Another study from India in 2014 included 69440 adults and children. The hemoglobin concentration was the lowest in children aged 6-30 months. Microcytic anemia was the most common anemia type in children and women. Iron deficiency was the most common etiology of severe anemia, as in our study (12). A total of 55 severe anemia and iron deficiency anemia patients were evaluated in a study and 23 (45\%) severe anemia patients diagnosed incidentally during a healthy child examination (13). In a study from US in 2014, a total of 64 severe anemia and iron deficiency anemia patients aged 13 to 36 months were evaluated and emphasized that the necessary precautions should be taken to avoid severe iron deficiency in infants aged 15 months and over (14). In our study, iron deficiency anemia was most frequently found in children aged 6 months to 5 years.

Reactive thrombocytosis is usually seen in iron deficiency anemia (15). Thrombocytopenia may also occur. We found thrombocytopenia at a rate of $15.4 \%$ and thrombocytosis at a rate of $28.8 \%$ in the children with severe anemia and iron deficiency anemia, similar to the rates reported in the literature. In a study on 4 children evaluating severe anemia has reported platelet levels below $50 \times 10^{3} / \mathrm{mm}^{3}$ in all the cases (16). We found the platelet count to be significantly lower in patients with a hemoglobin level $<6 \mathrm{~g} / \mathrm{dL}$ compared to those with $\geq 6 \mathrm{~g} / \mathrm{dL}$. Although the hemoglobin cut-off value for RBCs transfusion varies according to the child's age, transfusion is not indicated if the clinical condition is stable $(17,18)$. Our patients with the criteria of severe anemia received transfusions if they showed heart failure symptoms or were in respiratory distress due to a pulmonary disorder.

Our results gave similar results with the study conducted by Keskin et al. (19) in terms of specificity and sensitivity of RDW; in cases with RDW elevation, prophylactic dose 
iron replacement can be performed. In our study, cases with severe anemia were divided into two group as those with and without iron deficiency anemia. We found that, the sensitivity and specificity of RDW to diagnose iron deficiency anemia in patients with severe anemia was $71.2 \%$ and $74.6 \%$ while these values were $92.4 \%$ and $86.6 \%$ for $\mathrm{MCV}$, respectively. We concluded that iron replacement would prevent severe iron deficiency anemia by early diagnosis of iron deficiency in patients with high RDW and low MCV.

The distribution of the etiologies for severe anemia in this study was different when compared to other studies from developing countries. Still, iron deficiency, a potentially preventable medical problem, was the leading cause. The use of RBCs transfusions in almost a third of children with iron deficiency anemia may result in unnecessary transfusion-related complications. The association of RBCs transfusions with underlying disease and a higher MCV value affect the physicians' decision process. Improved attempts for the prevention of iron deficiency anemia in all children and improvements in the guidelines for RBC transfusion in children presenting with severe anemia are needed.

\section{REFERENCES}

1. Brugnara C, Oski FA, Nathan DG. Diagnostic approach to the anemic patient. In: Orkin SH, Nathan DG, Ginsburg D, Look AT, Fisher DE, Lux SE, editors. Nathan and Oski's hematology of infancy and childhood. 7 th ed. $7^{\text {th }}$ ed. Philadelphia: WB Saunders; 2009. p.455-66.

2. Chaparro CM, Suchdev PS. Anemia epidemiology, pathophysiology and etiology in low- and middleincome countries. Ann N Y Acad Sci. 2019;1450(1):15-31.

3. Zimmermann MB, Hurrell RF. Nutritional iron deficiency. Lancet. 2007;370(9586):511-20.

4. van Hensbrock MB, Jonker F, Bates I. Severe acquired anaemia in Africa: new concepts. Br J Haematol. 2011;154(6):690-5.

5. Kline NE. A practical approach to the child with anemia. J Pediatr Healt Care. 1996;10(3):99-105.
6. Kapil U, Tyagi M. Etiology of severe anemia amongst adolescent children. Indian J Pediatr. 2012;79(3):401-2.

7. Dicko A, Klion AD, Théra MA, Sagara I, Yalcouyé D, Niambele MB, et. al. The etiology of severe anemia in a village and periurban area in Mali. Blood. 2004;104(4):1198-200.

8. Bansal D, Totadri S. Common hematological disorders in children. Indian J Pediatr. 2014;81(1):42-50.

9. Güvenç H, Aygün AD, Soylu F, Kocabay K. Çocukluk döneminde derin anemi etyolojisinde demir eksikliğinin önemi. MN Pediatride Yönelişler. 1994;1:149-52.

10. Şimşek Ş, Büyükavcı M, Kaya MD, Akdağ R, Karakelleoğlu C. Anemia prevalance and it's etiologic factors in patients admitted to pediatric outpatients departments living moderately high altitude in Erzurum. Zeynep Kamil Tıp Bülteni. 2005;36(1):33-8.

11. Kılıçaslan Ö, Yıldırmak ZY, Urgancı N. Evaluation of patients hospitalised in pediatrics clinic for profound anemia and diagnosed as iron deficiency. Med Bull Sisli Etfal Hosp. 2014;48(3):234-8.

12. Alvarez-Uria G, Naik PK, Midde M, Yalla PS, Pakam R. Prevalence and severity of anaemia stratified by age and gender in rural India. Anemia. 2014;176182.

13. Kwiatkowski JL, West TB, Heidary N, Smith-Whitley $\mathrm{K}$, Cohen AR. Severe iron deficiency anemia in young children. J Pediatr. 1999;135(4):514-6.

14. Paoletti G, Bogen DL, Ritchey AK. Severe irondeficiency anemia still an issue in toddlers. Clin Pediatr (Phila). 2014;53(14):1352-8.

15. İnci Yildiz. Iron deficiency anemia. Turk Pediatri Ars. 2009;44(1):14-8.

16. Morris VK, Spraker HL, Howard SC, Ware RE, Reiss UM. Severe thrombocytopenia with iron deficiency anemia. Pediatr Hematol Oncol. 2010;27(5):413-9.

17. Reeve K, Jones H. Transfusion guidelines in children: I. Anaesth Intens Care Med. 2017;18(11):541-5.

18. Jones H, Reeve K. Transfusion guidelines in children: II. Anaesth Intens Care Med. 2017;18(11):546-50.

19. Keskin A, Polat A, Türk T, Sermez Y. The importance of red cell distribution width (RDW) in the early diagnosis of iron deficiency. Med Bull Haseki. 2000;38(2):119-21. 